University of Montana

ScholarWorks at University of Montana

8-2009

\title{
Tri-Trophic Linkages in Disease: Pathogen Transmission to Rainbow Trout Through Stonefly Prey
}

\author{
Sandra M. Adams \\ University of Montana - Missoula \\ Aaron S. Adams \\ University of Montana - Missoula \\ William E. Holben \\ University of Montana - Missoula, Bill.Holben@mso.umt.edu
}

Follow this and additional works at: https://scholarworks.umt.edu/biosci_pubs

Part of the Biology Commons

Let us know how access to this document benefits you.

\section{Recommended Citation}

Adams, Sandra M.; Adams, Aaron S.; and Holben, William E., "Tri-Trophic Linkages in Disease: Pathogen Transmission to Rainbow Trout Through Stonefly Prey" (2009). Biological Sciences Faculty Publications. 19.

https://scholarworks.umt.edu/biosci_pubs/19

This Article is brought to you for free and open access by the Biological Sciences at ScholarWorks at University of Montana. It has been accepted for inclusion in Biological Sciences Faculty Publications by an authorized administrator of ScholarWorks at University of Montana. For more information, please contact scholarworks@mso.umt.edu. 


\section{Tri-Trophic Linkages in Disease: Pathogen Transmission to Rainbow Trout Through Stonefly Prey}

Author(s): Sandra M. Adams, Aaron S. Adams, and William E. Holben

Source: Environmental Entomology, 38(4):1022-1027. 2009.

Published By: Entomological Society of America

DOI: http://dx.doi.org/10.1603/022.038.0409

URL: http://www.bioone.org/doi/full/10.1603/022.038.0409

BioOne (www.bioone.org) is a nonprofit, online aggregation of core research in the biological, ecological, and environmental sciences. BioOne provides a sustainable online platform for over 170 journals and books published by nonprofit societies, associations, museums, institutions, and presses.

Your use of this PDF, the BioOne Web site, and all posted and associated content indicates your acceptance of BioOne's Terms of Use, available at www.bioone.org/page/terms_of_use.

Usage of BioOne content is strictly limited to personal, educational, and non-commercial use. Commercial inquiries or rights and permissions requests should be directed to the individual publisher as copyright holder. 


\title{
Tri-Trophic Linkages in Disease: Pathogen Transmission to Rainbow Trout Through Stonefly Prey
}

\author{
SANDRA M. ADAMS, ${ }^{1}$ AARON S. ADAMS ${ }^{2}$ AND WILLIAM E. HOLBEN ${ }^{1,3,4}$
}

Environ. Entomol. 38(4): 1022-1027 (2009)

\begin{abstract}
Relationships between macroinvertebrates and microorganisms in aquatic environments are only poorly understood despite the fact that many aquatic macroinvertebrates feed on microbial biofilms during some life stage. Better understanding of trophic interactions between microbial biofilms, macroinvertebrates, and fish may also help control fish diseases and loss of natural resources. It has also been suggested that pollution, habitat fragmentation, and poor water quality may contribute to increased pathogenesis and mortality in fish. Increased disease incidence is difficult to assess, however, in part because of the complexity of pathogen transmission dynamics. Several environmental pathogens exist whose reservoir(s) and means of transmission remain poorly understood, highlighting the need to study pathogen ecology and interactions with organisms other than susceptible hosts. Aeromonas salmonicida is rarely isolated from freshwater sediments. However, stonefly nymphs were found to frequently harbor A. salmonicida and were shown to preferentially feed on the bacterium. Rainbow trout juveniles were presented with different feeding regimes to determine the transmission capacity of nymphs, and all fish fed stoneflies harboring A. salmonicida expressed symptoms of disease. Although current rates of furunculosis in freshwater ecosystems are unknown, trout primarily feed on stoneflies when water oxygen levels are high and temperatures are low (winter months), which is presumed to correspond to high resistance to the pathogen. Given that furunculosis is associated with physiological stress and higher water temperatures, its natural incidence may change in response to global or regional climatological effects.
\end{abstract}

KEY WORDS Plecoptera, insect feeding assay, Aeromonas salmonicida, disease-pathogen dynamics, trophic interactions

Prokaryotes and macroinvertebrates, such as stoneflies, collectively play key roles in the cycling of nutrients in surface waters (Huryn and Wallace 2000, Cummins et al. 2008). Additionally, microbial biomass accumulation is positively correlated to macroinvertebrate population density (Huryn and Wallace 2000), suggesting that both detritus and microbial biofilms contribute to macroinvertebrate nutrition. It has been suggested that many factors influence predation of bacteria by mesofauna in aquatic ecosystems, such as prokaryotic morphology, cell density, secondary metabolites, or nutritional content (Hahn and Höfle 2001, Huws et al. 2005, Jardillier et al. 2005). Although the relationships between macroinvertebrates and microorganisms in aquatic environments are only poorly understood, many aquatic macroinvertebrates feed on microbial biofilms during some life stage. Even the predacious stonefly nymphs feed on biofilms as early instars (Stewart and Stark 2002).

\footnotetext{
${ }^{1}$ Microbial Ecology Program, Division of Biological Sciences, The University of Montana, Missoula, MT, 59812.

${ }^{2}$ Department of Ecosystem and Conservation Sciences, The University of Montana, Missoula, MT, 59812.

${ }^{3}$ Montana-Ecology of Infectious Diseases Program, The University of Montana, Missoula, MT, 59812.

${ }^{4}$ Corresponding author, e-mail: bill.holben@mso.umt.edu.
}

Stoneflies are regarded as one of the most numerous insect orders in freshwater ecosystems (Stewart and Stark 2002) and represent a major nutrient source for trout (Duffield and Nelson 1998). In addition, the presence of stonefly nymphs has been to shown to impact trout behavior and increase growth and survival (Soluk and Richardson 1997). Stoneflies generally inhabit clean, clear, and cool waters (Stewart and Stark 2008), an environment preferred by trout species.

The bacterium, Aeromonas salmonicida subsp. salmonicida, is an opportunistic fish pathogen capable of causing the disease furunculosis (Fig. 1) in farm-raised salmonids and other freshwater and marine fish (Hiney et al. 1992, Austin 1997, Bernoth 1997, Ring $\varnothing$ et al. 2004). A. salmonicida, one the earliest fish pathogens studied, was first isolated from symptomatic fish over a century ago (Bernoth 1997, Gustafson et al. 1992). Originally thought to be an obligate pathogen incapable of surviving outside of a fish host (Gustafson et al. 1992, Hiney et al. 1992, Morgan et al. 1993), more recently it has been presumed to be a free-living opportunistic pathogen capable of causing disease in stressed hosts (e.g., caused by warm water and overcrowding) (Pickering 1997). To date, there has been no reported vector for $A$. salmonicida transmission to 


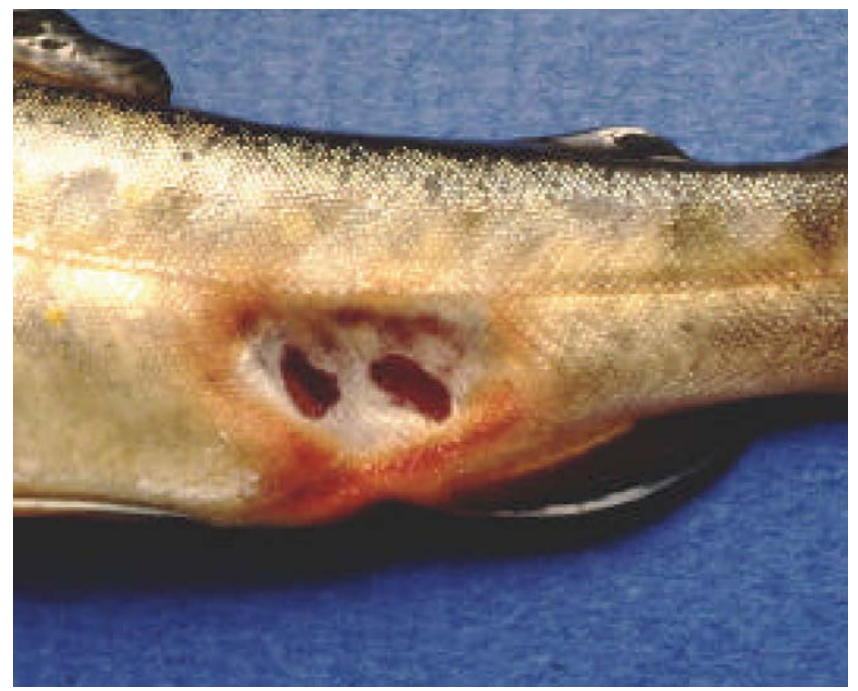

Fig. 1. Stonefly feeding behavior. Average time spent feeding on each bacterial strain is shown in seconds $(n=24)$. Error bars represent SE. Bars labeled with the same letter were not statistically significant $(P>0.05)$. (Online figure in color.)

fish, and it has been assumed that naïve fish populations acquire infection through contact with infected fish (Austin 1997). However, this bacterium has been observed in aquatic sediments only in low numbers and only through the use of molecular techniques (O’Brien et al. 1994, Austin 1997; unpublished data). Caused, in part, by the difficulty of culturing viable $A$. salmonicida from sediment and river environments, there are numerous questions regarding its persistence in the environment and its mode of transmission (see Austin 1997, Enger 1997).

The goal of this study was to examine where and how A. salmonicida survives outside of the fish host in natural freshwater environments and to explore possible modes of transmission beyond direct contact with infected individuals. We also were interested in questions regarding the natural history of this hostpathogen system, e.g., why the natural incidence of furunculosis in the open environment is low, and what environmental perturbations might upset that natural balance.

\section{Materials and Methods}

Recovery and analysis of insect hindgut microbial community DNA was performed on nine stoneflies collected in fall 2004. Hindguts were removed surgically, and total microbial DNA from the contents was subjected to random cloning of partial $16 \mathrm{~S}$ rRNA gene sequences as described elsewhere (Holben et al. 2002). Ten clones from each insect were randomly selected for DNA sequence analysis and phylotype identification using the RDPII online database and resources (Maidak et al. 2001). In addition, total DNA from the hindgut contents of 12 individual stonefly nymphs was tested for the presence of A. salmonicida by polymerase chain reaction (PCR) amplification with A. salmonicida-specific primers (Gustafson et al. 1992, Hiney et al. 1992).
Early-instar Paraperla frontalis (Banks) nymphs were obtained from the hyporheic zone in the Nyack floodplain near West Glacier, MT (fall 2004), and Petty Creek, Alberton, MT (winter 2005/2006). These were obtained either by pumping water from screened wells in or near the stream channel through fine nylon mesh (Nyack floodplain) or by use of a standard kick-net in shallow sediments in the streams (Nyack floodplain and Petty Creek).

Preferential feeding behavior of stonefly nymphs toward particular bacterial isolates was assessed using bacterial isolates from the Nyack site: Pedobacter isolate II-14, two Pseudomonas isolates, II-5 and I-73, and also the type strain A. salmonicida subsp. salmonicida (ATCC 33658; ATCC, Manassas, VA). Microbial isolate biofilms were developed by inoculating individual sterile filter disks (25-mm diameter, polypropylene, $0.45-\mu \mathrm{m}$ pore size; Millipore, Billerica, MA) with $25 \mu \mathrm{l}$ of an overnight culture grown in standard Luria-Bertani Broth (LB; Becton Dickinson, Sparks, MD) at $20^{\circ} \mathrm{C}$ and then incubating on a LB-saturated pad of Whatman No. 1 filter paper for $48 \mathrm{~h}$ at $20^{\circ} \mathrm{C}$. Negative control disks were not inoculated with bacteria but were otherwise treated identically. Petri dishes (sterile polystyrene, 150 by $15 \mathrm{~mm}$ ) used in the feeding assay held five disks of filter paper, four individually coated with biofilm from each bacterial isolate and one negative control disk. Petri dishes were gently flooded with $75 \mathrm{ml}$ of filter-sterilized river water, and the biofilm disks were evenly spaced in random order around the inside perimeter of each dish. Forty stonefly nymphs were starved for $24 \mathrm{~h}$ in filter-sterilized river water and introduced individually into the center of petri dishes under indirect red light at $4^{\circ} \mathrm{C}$. Each insect was monitored individually for $15 \mathrm{~min}$, and feeding time spent on each disk was recorded whenever an insect exhibited overt signs of feeding (defined as movement of head or mouthparts on a biofilm disc). Total time spent feeding (in seconds) for each 
individual on each treatment disk was $\log n+1$-transformed to normalize the data. Analysis of variance (ANOVA) was used to test the null hypothesis that feeding time on biofilm disks was independent of bacterial type. Forty insects were included in the assay; however, 16 did not respond and were not included in the analysis. No insects fed on the negative control disks; therefore, time spent feeding on control disks was not included in the analysis.

Hindgut dissection and frass collection was performed on 13 nymphs collected from the Nyack floodplain in fall 2004. Sediment obtained from same collection site was sterilized by autoclaving three times on 3 successive days to ensure sterility and destruction of bacterial endospores. Sterile sediment $(500 \mathrm{ml})$ was inoculated with $400 \mathrm{ml}$ of an overnight culture of $A$. salmonicida in trypticase soy broth (Difco; Becton, Dickinson, and company, Sparks, MO) at $20^{\circ} \mathrm{C}$ and incubated at $20^{\circ} \mathrm{C}$ for $2 \mathrm{~d}$ to facilitate infection of stoneflies with A. salmonicida. Excess media was drained away and the sediment placed in a shallow layer in 150 by $15-\mathrm{mm}$ petri dishes with $75 \mathrm{ml}$ of filtered-sterilized river water. Individual stonefly nymphs were placed in these dishes and maintained at $4^{\circ} \mathrm{C}$ for $5 \mathrm{~d}$ to feed on the A. salmonicida type strain biofilm.

Seven nymphs fed as described above were randomly chosen for hindgut dissection, and six were used for frass collection. For frass collection, insects were surface-washed with sterile $\mathrm{dH}_{2} \mathrm{O}$ and placed onto sterile filter paper saturated with filter-sterilized river water. Each hindgut content sample or frass sample was spread onto a separate TSA plate and incubated overnight at $20^{\circ} \mathrm{C}$. To verify the identity of putative A. salmonicida colonies, molecular fingerprint analysis was performed using repetitive extragenic palindromic polymerase chain reaction(REPPCR) (Hulton et al. 1991). Hindgut or frass isolates producing fingerprints $\geq 95 \%$ similar to the type strain as determined using BioNumerics v4.5 software (Applied-Maths, Austin, TX) were presumed to be A. salmonicida.

Transmission of A. salmonicida to trout through stoneflies was shown using juvenile rainbow trout weighing 80-100 g obtained from the Jocko Fish Hatchery (Arlee, MT) (February 2006), which had no history of furunculosis. Two fish were randomly selected before the start of the experiment, and their liver and kidney tissues were analyzed by PCR with $A$. salmonicida-specific primers (Gustafson et al. 1992, Hiney et al. 1992) to ensure that chronic A. salmonicida was not present in the fish population. Our experiment consisted of three treatments, each applied in duplicate 10 -gal, closed-system aquaria at $20^{\circ} \mathrm{C}$. For each aquarium, two individual fish were equilibrated in the system for $72 \mathrm{~h}$ without food. Treatments consisted of a daily allowance of $\approx 1 \%$ body weight of ( 1 ) unmanipulated stonefly nymphs; (2) stonefly nymphs fed the type strain of A. salmonicida; or (3) commercial fish diet (Rangens Fish Food, Buhl, ID). Animal husbandry, treatment application, and euthanasia for these experiments were performed in accordance with institutional guidelines according to IACUC 03805WHDBS-112905.

Fish exhibiting symptoms of disease (e.g., inability to swim, inflamed anus, or death) were scored positive for furunculosis. Fish were killed after being scored positive or at the end of $1 \mathrm{wk}$. Dissections were performed to obtain liver tissue DNA from each fish to confirm both positive and negative diagnosis for furunculosis by PCR. DNA was prepared using the Qiagen Blood and Cell Culture DNA Midi Kit (Qiagen, Valencia, CA) for PCR-based analysis using A. salmonicida-specific primers as described (Gustafson et al. 1992, Hiney et al. 1992).

\section{Results}

Recovery and Analysis of Stonefly Hindgut Microbial Community DNA. The majority of phylotypes obtained from stonefly nymph hindguts most closely matched uncultured bacteria. Approximately 32\% of sequences obtained from insects collected at the Nyack floodplain were most closely related to A. salmonicida, with an average $\mathrm{S}_{a b}$ score of 0.993 (14.8\% matched with a score of 1.000). PCR amplification of DNA isolated from hindgut contents with A. salmonicida-specific primers showed that $58 \%$ of stoneflies collected at Petty Creek harbored A. salmonicida.

Preferential Feeding Behavior of Stonefly Nymphs. Twenty-four of 40 stoneflies responded to the behavior assay (response rate $=60 \%$ ) and preferentially fed on A. salmonicida significantly more than all other bacteria tested ( $P<0.005 ;$ Fig. 2 ). No insect exhibited feeding behavior toward a negative control disk.

Aeromonas salmonicida Viability in Stonefly Hindguts and Frass. Viable A. salmonicida cells were obtained from all stonefly hindguts $(n=7)$ and all frass collections $(n=6)$ as determined by colony appearance and REP-PCR testing using the type strain as positive control (data not shown).

Transmission of A. salmonicida to Trout Through Stoneflies. Transmission of A. salmonicida to trout through stoneflies was shown in the aquarium experiment (Table 1). All trout fed unmanipulated stoneflies became symptomatic for furunculosis, showed evidence of acute infection, and subsequently died after $2 \mathrm{~d}$ of treatment. All trout fed A. salmonicida-fed stoneflies exhibited acute disease symptoms within $4 \mathrm{~d}$ after initiation of treatment and were killed before disease-related death. In contrast, none of the trout fed the commercial diet exhibited any disease symptoms during the 1-wk course of the experiment. All positive and negative diagnoses were confirmed by PCR.

\section{Discussion}

Our preliminary experiments in this system showed that the prevalence of $A$. salmonicida in $P$. frontalis stonefly nymphs was much higher than would be predicted by its prevalence in bulk sediment from Nyack. This initial observation led to additional experiments that showed that $P$. frontalis stonefly nymphs prefer- 


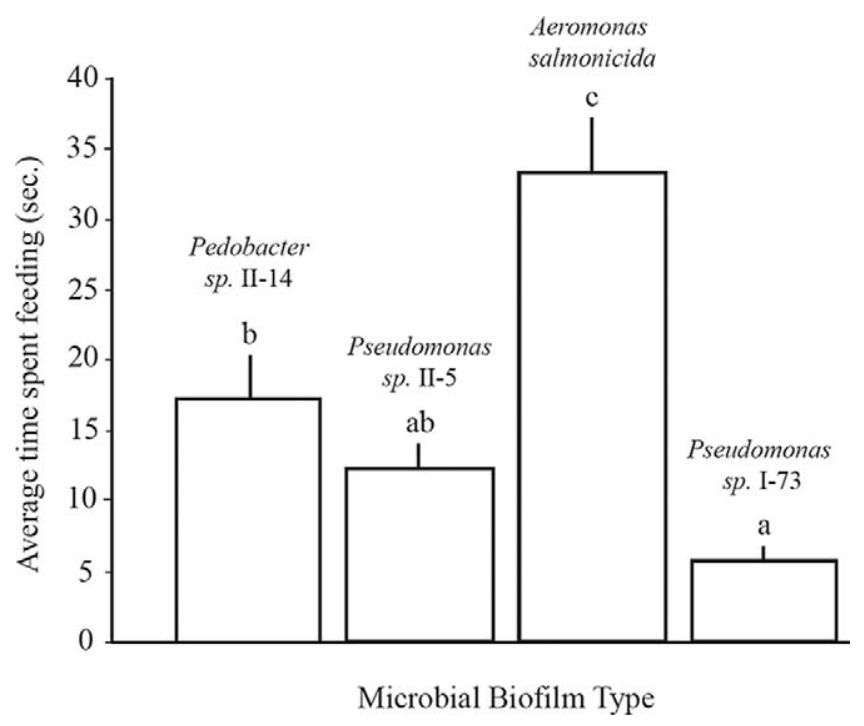

Fig. 2. Furunculosis caused by A. salmonicida subsp. salmonicida. The term furunculosis is derived from the furuncules, or deep ulcerations of tissue, often observed in infected fish. Photograph by R. Cipriano.

entially feed on A. salmonicida, may serve as a reservoir for this pathogen while also passing viable bacteria in their frass, and are capable of mediating its transmission to susceptible hosts in laboratory experiments. The observed symptoms of acute infection in both stonefly treatments in our study were consistent with induced infections in other studies where salmonid fish were injected with, or fed diets saturated with, A. salmonicida (Siwicki et al. 1994, Duffield and Nelson 1998, Ogut and Reno 2005). Also consistent with prior research findings, the indigenous strain of $A$. salmonicida harbored in the hindguts of local stoneflies in this study was more virulent than the type strain used as positive control (Stuber et al. 2003).

Despite the virulence of A. salmonicida in the laboratory, the pathogen is difficult to detect in freshwater ecosystems. An extensive 16S rRNA gene survey of the Nyack floodplain sediment microbial community detected A. salmonicida only once in a library of $>4,200$ sequences (data not shown). Despite this observation, our data showed that stonefly nymphs naturally harbor A. salmonicida in the hindgut compartment at high incidence. Thirty-three percent of stonefly individuals tested from the Nyack floodplain and 58\% from Petty Creek harbored bacteria whose 16S rRNA gene sequence was essentially identical to

Table 1. Disease transmission to trout by stonefly nymphs

\begin{tabular}{lccc}
\hline \hline & $\begin{array}{c}\text { Nymphs with } \\
\text { indigenous } \\
\text { microflora }\end{array}$ & $\begin{array}{c}\text { Nymphs fed } \\
\text { A. salmonicida } \\
\text { type strain }\end{array}$ & $\begin{array}{c}\text { Nymphs fed } \\
\text { commercial diet }\end{array}$ \\
\hline Day 0 & ++++ & ++++ & ++++ \\
Day 2 & XXXX & ++++ & ++++ \\
Day 4 & & XXXX & ++++ \\
Day 7 & & & ++++ \\
\hline
\end{tabular}

+ , no. of individuals showing no signs of disease; $x$, no. of individuals showing clear signs of disease. the A. salmonicida type strain $\left(\mathrm{S}_{a b} \geq 0.993\right)$. The difference in A. salmonicida prevalence between freshwater sediment and stonefly hindguts may be because of the observed feeding preference for A. salmonicida biofilm and/ or to bioamplification within the hindgut. In addition to $A$. salmonicida sources in sediment, dead or diseased fish are considered a major source of $A$. salmonicida in freshwater ecosystems, and stonefly nymphs are among the first and most abundant macroinvertebrates to colonize salmon carcasses (Chaloner et al. 2002). Indeed, there are several opportunities for stonefly nymphs to encounter A. salmonicida in the environment. Whether A. salmonicida is fed on in the sediment or from deceased fish, preferential feeding on this bacterium may be explained by nutritional requirements for insect development. For example, A. salmonicida is known to secrete melanin, a highly pigmented secondary metabolite derived from tyrosine (Koppang et al. 2000) that is critical to the sclerotization and pigmentation of the insect cuticle (Kramer and Hopkins 2005).

Although the data obtained in our small-scale initial transmission study strongly suggest that stoneflies can transmit infectious titers of A. salmonicida to salmonid fish under stressful laboratory conditions (closed-system aquaria at $20^{\circ} \mathrm{C}$ ), additional larger-scale experiments with greater replication and perhaps additional treatments should be performed to conclusively establish this point. It has been suggested that A. salmonicida is an opportunistic pathogen that causes disease only under certain conditions, most notably high temperature and crowding (Pickering 1997). In winter months, stoneflies constitute a large portion of the trout diet (Tippets and Moyle 1978, Duffield and Nelson 1998). However, as temperatures of surface waters rise in summer months, stoneflies become less abundant. Thus, when trout are most susceptible to the 
disease, i.e., during warm water temperatures (Pickering 1997), and in Montana, low-water conditions, stoneflies and the A. salmonicida that our results suggest they carry are not as readily available as a food source. In addition, it has been suggested that when fish are exposed to pathogens in lower water temperatures, their immune system may be stimulated, rather than succumbing to disease at higher water temperatures (Köllner and Kotterba 2002, Nikoskelainen et al. 2004). Thus, stonefly nymphs in natural aquatic habitats under normal conditions may play a role in strengthening the host fish immune response. This may explain why large numbers of native fish do not succumb to furunculosis in the natural environment, and outbreaks of disease are generally confined to hatcheries where fish densities and water temperatures are generally higher. Importantly, as temperatures increase because of global warming trends and environmental dynamics subsequently shift, the balance of trophic interactions such as these may be upset, ultimately affecting the dynamics of this and perhaps other diseases. Clearly, additional research is warranted to better elucidate the specific interactions between stoneflies (and other macroinvertebrates), trout, and bacteria to more fully understand disease transmission and host pathogen dynamics in aquatic systems.

\section{Acknowledgments}

We thank J. Gannon, N. Gordon, and A. Valenzuela for providing bacterial strains. We also thank L. Eby for laboratory space for aquarium experiments, advice regarding disease transmission experiments, and helpful comments on the manuscript. We are grateful to M. A McCrackin for helpful advice regarding animal experiments and institutional guidelines. We thank G. Kirsch for kindly providing juvenile fish and R. Cipriano for permission to use the photograph depicted in Fig. 1. We gratefully acknowledge excellent technical support by T. Westlie and L. Schimmelpfennig. Finally, we thank D. Six, W. Snyder, J. Lowell, C. Noonan, and B. Peckarsky for reviewing and providing helpful comments on the manuscript before submission. This work was supported by NSF Microbial Observatory Grant MCB-0348773.

\section{References Cited}

Austin, B. 1997. Progress in understanding the fish pathogen Aeromonas salmonicida. Marine Biotechnol. 15: 131-134.

Bernoth, E. M. 1997. Furunculosis: the history of disease and of disease research, pp. 1-20. In E. M. Bernoth, A. Ellis, P. J. Midtlyng, G. Oliver, and P. Smith (eds.), Furunculosis: multidisciplinary fish disease and research. Academic, San Diego, CA.

Chaloner, D. T., M. S. Wipfli, and J. P. Caouette. 2002. Mass loss and macroinvertebrate colonization of Pacific salmon carcasses in south-eastern Alaskan streams. Freshwater Biol. 47: 263-273.

Cummins, K. W., R. W. Merritt, and M. B. Berg. 2008. Ecology and distribution of aquatic insects, pp. 105-122. In R. W. Merritt, K. W. Cummins, and M. B. Berg (eds.), An introduction to the aquatic insects of North America, 4th ed. Kendall/Hunt Publishing, Dubuque, IA.
Duffield, R. M., and C. H. Nelson. 1998. Stoneflies (Plecoptera) in the diet of brook trout (Salvelinus frontinalis Mitchell) in Libby Creek, Wyoming, USA. Hydrobiologia 380: 59-65.

Enger, Ø. 1997. Survival and inactivation of Aeromonas salmonicida outside the host - a most superficial way of life, pp. 159-177. In E. M. Bernoth, A. Ellis, P. J. Midtlyng, G. Oliver, and P. Smith (eds.), Furunculosis: multidisciplinary fish disease and research. Academic, San Diego, CA.

Gustafson, C. E., C. J. Thomas, and T. J. Trust. 1992. Detection of Aeromonas salmonicida from fish by using polyermase chain reaction amplification of the virulence surface array protein gene. Appl. Environ. Microbiol. 58: $3816-3825$.

Hahn, M. W., and M. G. Höfle. 2001. Grazing of protozoa and its effect on populations of aquatic bacteria. FEMS Microbiol. Ecol. 35: 175-185.

Hiney, M., D. Dawson, D. Heery, P. R. Smith, F. Gannon, and R. Powell. 1992. DNA Probe for Aeromonas salmonicida. Appl. Environ. Microbiol. 58: 1039-1042.

Holben, W. E., P. Williams Saarinen, M. Särkilahti, and J.H.A. Apajalhti. 2002. Phylogenetic analysis of intestinal microflora indicates a novel Mycoplasma phylotype in farmed and wild salmon. Microbial Ecol. 44: 175-185.

Hulton, C. S., C. F. Higgins, and P. M. Sharp. 1991. ERIC sequences: a novel family of repetitive elements in the genomes of Escherichia coli, Salmonella typhimurium and other enterobacteria. Molec. Microbiol. 5: 825-834.

Huryn, A. D., and J. B. Wallace. 2000. Life history and production of stream insects. Annu. Rev. Entomol. 45: 83-110.

Huws, S. A., A. J. McBain, and P. Gilbert. 2005. Protozoan grazing and its impact upon population dynamics in biofilm communities. J. Appl. Microbiol. 98: 238-244.

Jardillier, L., D. Boucher, S. Personnic, S. Jacquet, A. Thènot, D. Sargos, C. Amblard, and D. Debroas. 2005. Relative importance of nutrients and mortality factors on prokaryotic community composition in two lakes of different trophic status: microcosm experiments. FEMS Microbiol. Ecol. 53: 429-443.

Köllner, B., and G. Kotterba. 2002. Temperature dependent activation of leucocyte populations of rainbow trout, $\mathrm{On}$ corhynchus mykiss, after intraperitoneal immunisation with Aeromonas salmonicida. Fish Shellfish Immunol. 12: 35- 48.

Koppang, E. O., M. Fjølstad, B. Melgård, M. Vigerust, and H. S. Sørum. 2000. Non-pigment-producing isolates of Aeromonas salmonicida subspecies salmonicida: isolation, identification, transmission and pathogenicity in Atlantic salmon, Salmo salar L. J. Fish Dis. 23: 39-48.

Kramer, K. J., and T. L. Hopkins. 2005. Tyrosine metabolism for insect cuticle tanning. Arch. Insect Biochem. Physiol. 6: 279-301.

Maidak, B. L., J. R. Cole, T. G. Lilburn, C. T. Parker, P. R. Saxman, R. J. Farris, G. M. Garrity, G. J. Olsen, T. M. Schmidt, and J. M. Tiedje. 2001. The RDP-II (Ribosomal Database Project). Nucleic Acid Res. 29: 173-174.

Morgan, J.A.W., G. Rhodes, and R. W. Pickup. 1993. Survival of nonculturable Aeromonas salmonicida in lake water. Appl. Environ. Microbiol. 59: 874-880.

Nikoskelainen, S., G. Bylund, and E. M. Lilius. 2004. Effect of environmental temperature on rainbow trout $(\mathrm{On}$ corhynchus mykiss) innate immunity. Dev. Comp. Immunol. 28: 581 .

O’Brien, D., J. Mooney, D. Ryan, E. Powell, M. Hiney, P. R. Smith, and R. Powell. 1994. Detection of Aeromonas salmonicida, causal agent of furunculosis in salmonid fish, 
from the tank effluent of hatchery-reared Atlantic salmon smolts. Appl. Environ. Microbiol. 60: 3874-3877.

Ogut, H., and P. W. Reno. 2005. Evaluation of an experimental Aeromonas salmonicida epidemic in Chinook salmon, Oncorhynchus tshawytscha (Walbaum). J. Fish Dis. 28: 263-269.

Pickering, A. D. 1997. Husbandry and stress, pp. 178-202. In E. M. Bernoth, A. Ellis, P. J. Midtlyng, G. Oliver, and P. Smith (eds), Furunculosis: multidisciplinary fish disease and research. Academic, San Diego, CA.

Ring $\varnothing$, E., F. Jutfelt, P. Kanapathippillai, Y. Bakken, K. Sundell, J. Glette, T. M. Mayhew, R. Myklebust, and R. E. Olsen. 2004. Damaging effect of the fish pathogen Aeromonas salmonicida subsp. salmonicida on intestinal enterocytes of Atlantic salmon (Salmo salar L.). Cell Tissue Res. 318: 305-311.

Siwicki, D., P. Anderson, and G. L. Rumsey. 1994. Dietary intake of immunostimulants by rainbow trout affects nonspecific immunity and protection against furunculosis. Vet. Immunol. Immunopathol. 41: 125-139.
Soluk, D. A., and J. S. Richardson. 1997. The role of stoneflies in enhancing growth of trout: a test of the importance of predator-predator facilitation within a stream community. Oikos 80: 214-219.

Stewart, K. W., and B. P. Stark. 2002. Nymphs of North American stonefly genera (Plecoptera), 2nd ed. Caddis Press, Columbus, $\mathrm{OH}$.

Stewart, K. W., and B. P. Stark. 2008. Plecoptera, pp. 311384. In R. W. Merritt, K. W. Cummins, and M. B. Berg (eds.), An introduction to the aquatic insects of North America, 4th ed. Kendall/Hunt Publishing, Dubuque, IA.

Stuber, K., S. E. Burr, M. Braun, T. Wahli, and J. Frey. 2003. Type III secretion genes in Aeromonas salmonicida subsp. salmonicida are located on a large thermolabile virulence plasmid. J. Clin. Microbiol. 41: 3854-3856.

Tippets, W. E., and P. B. Moyle. 1978. Epibenthic feeding by rainbow trout (Salmo gairdneri) in the McCould River, California. J. Anim. Ecol. 47: 549-559.

Received 5 September 2008; accepted 29 April 2009. 